\title{
First Total Synthesis of Cryptopyranmoscatone A3 and Crypto- pyranmoscatone B4
}

\author{
A. Maheswara Reddy \\ Gowravaram Sabitha* \\ Natural Products Chemistry Division, CSIR-Indian Institute of \\ Chemical Technology, Hyderabad 500007, India \\ gowravaramsr@yahoo.com \\ sabitha@iict.res.in
}

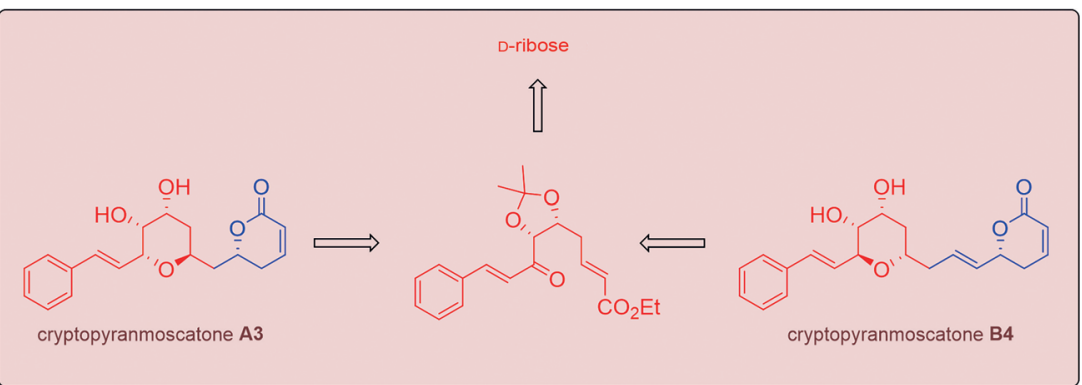

Received: 04.10.2017

Accepted after revision: 20.01.2018

Published online: 27.02 .2018

DOI: 10.1055/s-0036-1591931; Art ID: so-2017-d0044-op

License terms: cc)

Abstract The first total synthesis of cryptopyranmoscatones $A 3$ and B4 has been accomplished from D-ribose or but-3-ynol. The key steps involved in the synthesis are oxa-Michael addition, highly diastereoselective Brown allylation, and ring closing metathesis (RCM) and cross metathesis $(\mathrm{CM})$ reactions.

Key words oxa-Michael addition, Brown asymmetric allylation, ringclosing metathesis, cross metathesis

Natural products possessing $\alpha, \beta$-unsaturated $\delta$-lactone moieties have attracted considerable attention because of their promising pharmacological properties, which include anticancer, ${ }^{1,2}$ antimicrobial, ${ }^{3}$ antifungal, ${ }^{4}$ and insecticidal activity. ${ }^{5}$ Cryptopyranmoscatones A1, A2, A3, B1, B2, and B4 (1-6; Figure 1) were isolated by Cavalheiro and Yoshida ${ }^{6}$ from the branch and stem bark of Cryptocarya moschata, Lauraceae in 2000, together with other representative structures. This tree grows up to $30-40 \mathrm{~m}$ high, mainly in the Southeastern Region of Brazil. The structures of these compounds were established by spectroscopic methods. Based on circular dichroism measurements, the authors were able to set the absolute configuration at C6 as $R$. Structurally, these styryl lactones incorporate a dihydro- $\alpha$-pyrone moiety as well as a tetra-substituted tetrahydropyran ring. In preliminary biological studies, the cryptomoscatone family of compounds showed G2 checkpoint inhibitory properties $^{7}$ and cytotoxicity against human cervical carcinoma cell lines. ${ }^{8}$ Cryptocaryalactones belonging to this group are natural germination inhibitors, although they have no effect on corn. ${ }^{9}$ Extracts of Cryptocarya species have shown cyclooxygenase- 1 and -2 inhibition. ${ }^{10}$ At least some of these pharmacological effects may be related to the presence of the conjugated double bond, which acts as a Michael acceptor. The biological activity of the cryptopyranmoscatones has not been studied, presumably because of the limited supply from natural sources. The fascinating structural architecture and scarcity of these natural products have attracted our attention with the aim to develop a general synthetic strategy to prepare them.

As part of our continued efforts towards the synthesis of biologically active natural lactones, ${ }^{11}$ we have already reported the first total synthesis of cryptopyranmoscatones $\mathrm{A} 1,{ }^{12} \mathrm{~A} 2,{ }^{13}$ and $\mathrm{B} 1 .{ }^{14}$ In the present communication, we herein report the first stereoselective total synthesis of cryptopyranmoscatones A3 and B4 either from but-3-ynol or from D-ribose in a synthetic pathway via an intermediate from which both cryptopyranmoscatone A3 and B4 could be obtained.

Our retrosynthetic strategy for cryptopyranmoscatone A3 and B4 is depicted in Scheme 1. We envisaged that both cryptopyranmoscatone A3 and B4 could be obtained from a common intermediate 7 by adopting a stereoselective reduction, oxa-Michael addition reaction protocol. The analysis reveals that target compound $\mathbf{3}$ could be synthesized from bis-olefin $\mathbf{8}$ by utilizing a ring closing metathesis reaction, while the bis-olefin itself could be obtained from 9 by successive reactions involving oxidation and allylation followed by acrylation. The 2,6-trans-tetrasubstituted tetrahydropyran ring in compound $\mathbf{9}$ could be constructed from a common intermediate $\mathbf{7}$. In turn, intermediate $\mathbf{7}$ could be obtained via lactone $\mathbf{1 5}$ through a phenylacetylene addition reaction of the aldehyde, produced from the corresponding primary alcohol 13, which could be derived from D-ribose. Cryptopyranmoscatone B4 (6) could be prepared from compound 10 by performing a cross-metathesis reaction as the key step; whereas, the precursor, 2,6-trans-tetrahydropyran $\mathbf{1 1}$ could be obtained from intermediate $\mathbf{7}$. 
<smiles>O=C1C=CCC(CC2CC(O)[C@H](O)C(/C=C/c3ccccc3)O2)O1</smiles>

cryptopyranmoscatone A1 (1)<smiles>O=C1C=CCC(CC2CC(O)C(O)[C@@H](/C=C/c3ccccc3)O2)O1</smiles>

cryptopyranmoscatone A2 (2)<smiles>O=C1C=CCC(CC2C[C@H](O)[C@H](O)[C@H](/C=C/c3ccccc3)O2)O1</smiles>

cryptopyranmoscatone A3 (3)<smiles>O=C1C=CCC(/C=C/CC2C[C@H](O)[C@H](O)[C@H](/C=C/c3ccccc3)O2)O1</smiles>

cryptopyranmoscatone B1 (4)<smiles>O=C1C=CCC(/C=C/CC2CC(O)C(O)[C@@H](/C=C/c3ccccc3)O2)O1</smiles>

cryptopyranmoscatone B2 (5)<smiles>O=C1C=CC[C@H](/C=C/C[C@@H]2CC(O)[C@H](O)[C@H](/C=C/c3ccccc3)O2)O1</smiles>

cryptopyranmoscatone B4 (6)
Figure 1 Structures of natural cryptopyranmoscatones

The synthesis of the key intermediate 7 started with the known alcohol 13 (Scheme 2). Initially, we planned to prepare $\mathbf{1 3}$ from benzoate diol $\mathbf{1 2}^{15}$ in a three-step sequence by protecting group manipulations involving TBS protection followed by removal of the benzoyl and benzyl groups. The known benzoate diol 12 could be prepared in five steps by following reported procedures. However, bearing in mind the number of steps involved and overall yield in obtaining alcohol 13, it was alternatively prepared from D-ribose in five steps in an overall yield of $70 \% .{ }^{16}$ After protecting the free hydroxy group in $\mathbf{1 3}$ as its pivaloyl ether 16, the TBS group was removed with tetrabutylammonium fluoride (TBAF) to yield the corresponding alcohol 17. Oxidation of alcohol 17 with 2-iodoxybenzoic acid (IBX) gave an aldehyde that was subjected to Grignard addition with phenyl acetylene to give propargyl alcohol 18 as a mixture of diastereomers in 88:12 ratio (determined by chiral HPLC). ${ }^{17}$ This inseparable mixture was carried on to the preparation of ketone intermediate keto 7 . Thus, partial reduction of the triple bond in 18 with Red-Al furnished diol 19. Oxidative cyclization of 1,5-diol 19 with 2,2,6,6-tetramethyl-1-piperidinyloxy (TEMPO) and [bis(acetoxy)iodo]benzene (BAIB) ${ }^{18}$ produced the desired $\delta$-lactone $\mathbf{1 5}$ in 86\% yield. Lactone $\mathbf{1 5}$ was reduced to the lactol using diisobutylaluminum hydride (DIBAL-H) and subjected to Wittig olefination using the two carbon stabilized ylide to furnish $\alpha$. $\beta$-unsaturated ester $\mathbf{2 0}$ in 78\% overall yield (Scheme 2). IBX oxidation of $\mathbf{2 0}$ furnished the key intermediate 7 , from which both target molecules cryptopyranmoscatone A3 and B4 could be synthesized by adopting a chemoselective reduction of the keto group.

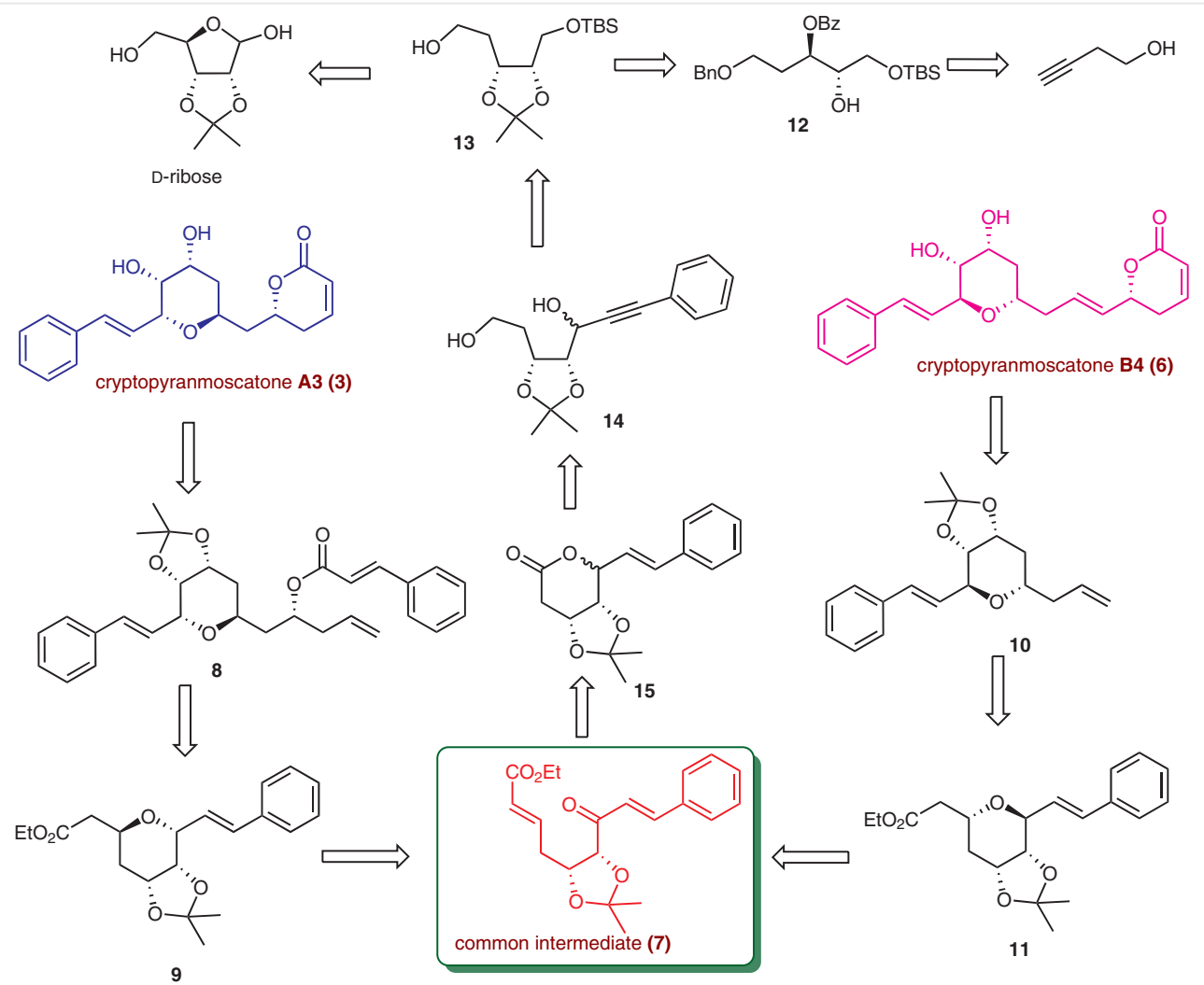

Scheme 1 Retrosynthetic analysis for cryptopyranmoscatone A3 and B4 


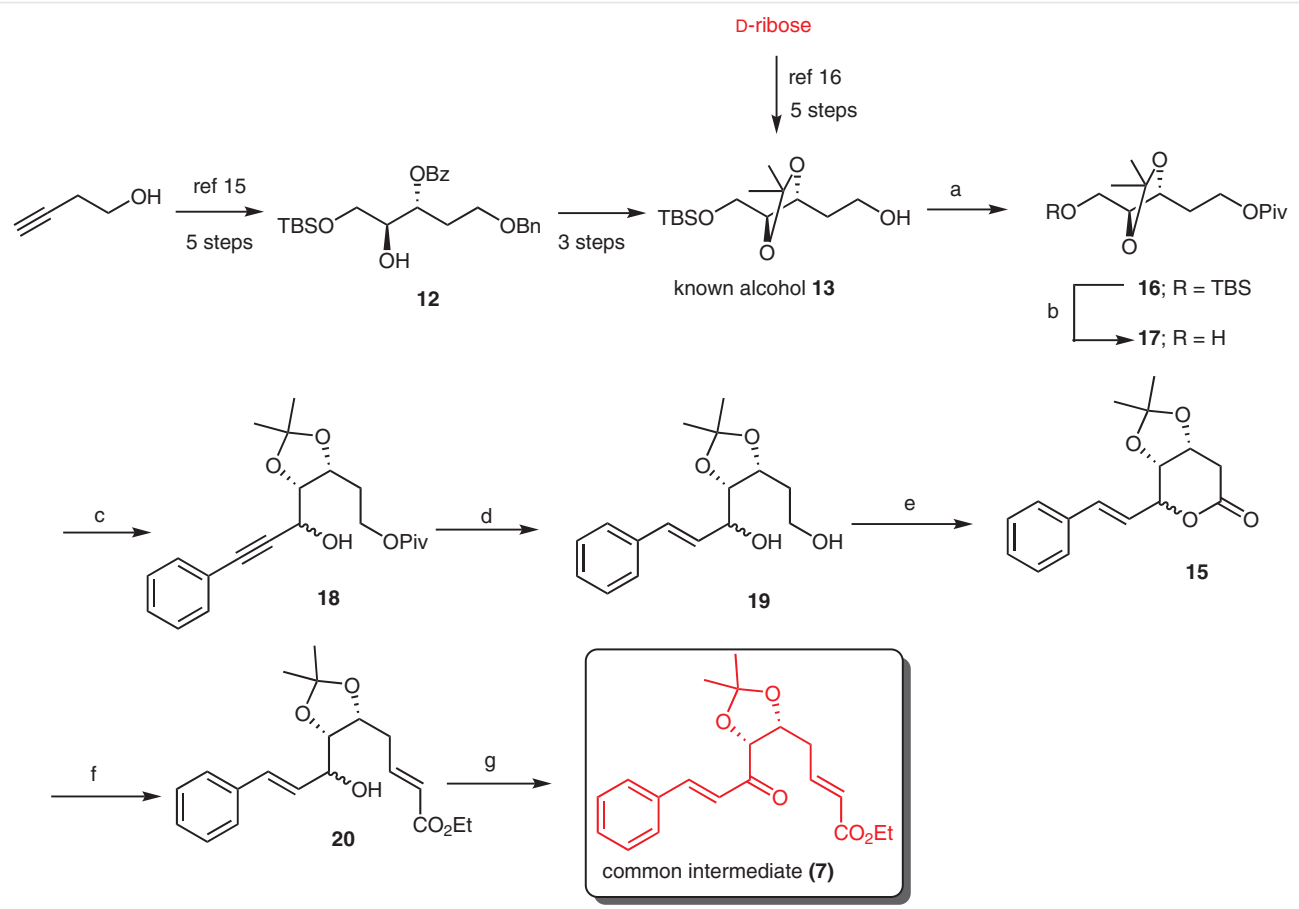

Scheme 2 Synthesis of key intermediate 7. Reagents and conditions: (a) PivCl, $\mathrm{Et}_{3} \mathrm{~N}, \mathrm{CH}_{2} \mathrm{Cl}_{2}, 0{ }^{\circ} \mathrm{C}, 4 \mathrm{~h}, 90 \%$; (b) TBAF, THF, $0{ }^{\circ} \mathrm{C}, 0.5 \mathrm{~h}, 90 \%$; (c) (i) IBX, $\mathrm{CH}_{3} \mathrm{CN}, \triangle, 1$ h; (ii) EtMgBr, phenylacetylene, THF, r.t., 1 h, 80\%; (d) Red-Al, THF/r.t., $90 \%$; (e) BAIB, TEMPO, $\mathrm{CH}_{2} \mathrm{Cl}_{2}$, r.t., 2 h, $86 \%$; (f) (i) DIBAL-H, $\mathrm{CH}_{2} \mathrm{Cl}$, $-78{ }^{\circ} \mathrm{C}$; (ii) $\mathrm{Ph}_{3} \mathrm{P}=\mathrm{CHCO}_{2} \mathrm{Et}, \mathrm{C}_{6} \mathrm{H}_{6}$, reflux, $1 \mathrm{~h}, 85 \%$; (g) IBX, $\mathrm{CH}_{3} \mathrm{CN}, \Delta, 1 \mathrm{~h}, 90 \%$.

Accordingly, the synthesis of A3 (3) commenced with stereoselective reduction of the keto group in 7 using $\mathrm{NaBH}_{4}$ in the presence of $\mathrm{CeCl}_{3} \cdot 7 \mathrm{H}_{2} \mathrm{O}$ at $-78{ }^{\circ} \mathrm{C}$ in $\mathrm{MeOH}$ to furnish the syn alcohol 21, the properties of which correlated with those reported..$^{19}$ The hydroxyester $\mathbf{2 1}$, on exposure to $t$ - $\mathrm{BuOK}^{20}$ in THF at $-78{ }^{\circ} \mathrm{C}$, readily underwent intramolecular oxa-Michael reaction to afford 2,6-trans tetrahydropyran 9 as a single diastereomer (>20:1) in 95\% yield (Scheme 3).<smiles>CCOC(=O)CC=CC[C@H]1OC(C)(C)O[C@@H]1[C@H](O)/C=C/c1ccccc1</smiles><smiles>C=CC[C@H](O)C[C@H]1C[C@H]2OC(C)(C)O[C@@H]2C(/C=C/c2ccccc2)O1</smiles>

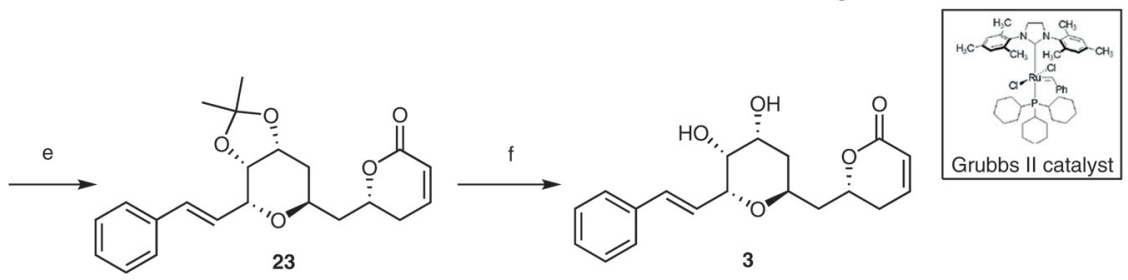

Scheme 3 Synthesis of cryptopyranmoscatone A3 (3). Reagents and conditions: (a) $\mathrm{NaBH}_{4}, \mathrm{CeCl}_{3} \cdot 7 \mathrm{H}_{2} \mathrm{O}, \mathrm{MeOH}, 1 \mathrm{~h}, 85 \%$; (b) $t$-BuOK, $\mathrm{THF},-78{ }^{\circ} \mathrm{C}, 0.5 \mathrm{~h}$, 95\%; (c) (i) DIBAL-H, $\mathrm{CH}_{2} \mathrm{Cl}_{2},-78^{\circ} \mathrm{C}$; (ii) (+)-IPC $\mathrm{B}\left(\right.$ allyl), ether, $-100^{\circ} \mathrm{C}, 1 \mathrm{~h}, 80 \%$; (d) cinnamic acid, $\mathrm{Et}_{3} \mathrm{~N}, \mathrm{~N}, \mathrm{~N}$-dicyclohexylcarbodiimide (DCC), 4-(N,Ndimethylamino)pyridine (DMAP), $\mathrm{CH}_{2} \mathrm{Cl}_{2}, 0{ }^{\circ} \mathrm{C}, 12 \mathrm{~h}, 85 \%$; (e) Grubbs Il catalyst, $\mathrm{CH}_{2} \mathrm{Cl}_{2}$, reflux, 6 h, $90 \%$; (f) $\mathrm{TiCl}_{4}, \mathrm{CH}_{2} \mathrm{Cl}_{2}, 0{ }^{\circ} \mathrm{C}, 15 \mathrm{~min}, 80 \%$. 
The trans-stereochemistry of the newly generated ring junction of tetrahydropyran 9 was assigned based on ${ }^{1} \mathrm{H}$ $\operatorname{NMR}\left(600 \mathrm{MHz}, \mathrm{CDCl}_{3}\right)$ data and assignments were made with the aid of TOCSY and NOESY experiments (see SI, Figure 2). The medium NOE enhancement between $\mathrm{C} 2 \mathrm{H} / \mathrm{C} 6 \mathrm{H}$ suggested that both protons are anti to each other (trans related). This was further supported by the NOE correlations between $\mathrm{C} 2 \mathrm{H} / \mathrm{Me}-\mathrm{a}, \mathrm{C} 4 \mathrm{H} / \mathrm{C} 6 \mathrm{H}, \mathrm{C} 2 \mathrm{H} / \mathrm{C} 5 \mathrm{H}$, and $\mathrm{C} 3 \mathrm{H} / \mathrm{C} 4 \mathrm{H}$.

After confirming the structure, the ester group in $\mathbf{9}$ was reduced with DIBAL-H and the resulting aldehyde was subjected to Brown's asymmetric allylation ${ }^{21}$ using (+)- $\mathrm{Ipc}_{2} \mathrm{~B}-$ allyl to furnish the homoallylic alcohol 22 in $80 \%$ overall yield over the two-step sequence. Subsequent coupling of alcohol 22 with cinnamic acid using DCC-DMAP provided diene 8 in $85 \%$ yield. Ring closing metathesis $(\mathrm{RCM})^{22}$ of diene 8 using the second-generation Grubbs' catalyst in $\mathrm{CH}_{2}$ $\mathrm{Cl}_{2}$ under refluxing conditions yielded lactone $\mathbf{2 3}$ exclusively. Finally, removal of the acetonide group using trifluoroacetic acid (TFA) in $\mathrm{CH}_{2} \mathrm{Cl}_{2}$ at $0{ }^{\circ} \mathrm{C}$ to room temperature for $0.5 \mathrm{~h}$ furnished cryptopyranmoscatone A3 (3) in 80\% yield. The spectroscopic and physical data of synthetic $\mathbf{3}$ are in agreement with those of the natural compound; thereby confirming its structure and absolute stereochemistry.

We then focused on the synthesis of cryptopyranmoscatone B4 (6) from common intermediate 7 , which, on DIBAL-H reduction, ${ }^{23}$ produced anti-alcohol 24 following a reported precedent (Scheme 4 ). The hydroxy ester $\mathbf{2 4}$, on exposure to $t$-BuOK in THF at $-78^{\circ} \mathrm{C}$, readily underwent intramolecular oxa-Michael reaction ${ }^{20}$ to afford 2,6-trans tetrahydropyran $\mathbf{1 1}$ as mainly a single diastereomer (>20:1) in $90 \%$ yield. The trans-stereochemistry of the newly generated ring-junction of tetrahydropyran $\mathbf{1 1}$ was assigned based on ${ }^{1} \mathrm{H}$ NMR (600 $\mathrm{MHz}, \mathrm{CDCl}_{3}$ ) analysis, with the aid of
TOCSY and NOESY experiments. The moderate NOE between $\mathrm{C} 2 \mathrm{H} / \mathrm{C} 6 \mathrm{H}$ suggested that both protons are anti to each other (trans related). This was further supported by the NOE correlations between $\mathrm{C} 2 \mathrm{H} / \mathrm{Me}-\mathrm{a}, \mathrm{C} 4 \mathrm{H} / \mathrm{C} 6 \mathrm{H}$, $\mathrm{C} 2 \mathrm{H} / \mathrm{C} 5 \mathrm{H}$, and $\mathrm{C} 3 \mathrm{H} / \mathrm{C} 4 \mathrm{H}$, confirming the structure.

After establishing the structure, the ester group in $\mathbf{1 1}$ was converted into a terminal alkene by reduction using DIBAL-H in $\mathrm{CH}_{2} \mathrm{Cl}_{2}$ followed by Wittig reaction to afford $\mathbf{1 0}$. Cross-metathesis ${ }^{24}$ reaction of terminal alkene with the known vinyl lactone $\mathbf{2 5}^{25}$ was carried out using Grubbs' second generation catalyst in $\mathrm{CH}_{2} \mathrm{Cl}_{2}$ under refluxing conditions for $4 \mathrm{~h}$ to afford the desired lactone 26. Finally, removal of the acetonide was achieved by treatment with TFA in $\mathrm{CH}_{2} \mathrm{Cl}_{2}$ at $0{ }^{\circ} \mathrm{C}$ to room temperature for $0.5 \mathrm{~h}$ to give the cryptopyranmoscatone $\mathrm{B} 4(\mathbf{6})$ in $80 \%$ yield. The spectroscopic and physical data of synthetic $\mathbf{6}$ are in agreement with those of the natural compound, thereby confirming its structure and absolute stereochemistry.

In conclusion, we have achieved the first total synthesis of cryptopyranmoscatones A3 and B4. The key steps involved in the synthesis are oxa-Michael addition, asymmetric allylation, and metathesis reactions.

All reactions were performed under inert atmosphere. All glassware used for performing the reactions was oven- or flame-dried. Anhydrous solvents were distilled prior to use: THF from Na and benzophenone; $\mathrm{CH}_{2} \mathrm{Cl}_{2}$ from $\mathrm{CaH}_{2}$; $\mathrm{MeOH}$ from $\mathrm{Mg}$. Commercial reagents were used without purification. Column chromatography was carried out using silica gel (60-120 mesh) unless otherwise mentioned. Analytical thin-layer chromatography (TLC) was run on silica gel $60 \mathrm{~F}_{254}$ pre-coated plates $\left(250 \mu \mathrm{m}\right.$ thickness). Specific rotations $[\alpha]_{D}$ were measured with a polarimeter and given in $10^{-1} \mathrm{deg} \mathrm{cm}^{2} \mathrm{~g}^{-1}$. Infrared spectra were recorded in $\mathrm{CHCl}_{3}$ or as $\mathrm{KBr}$ discs (as mentioned) and reported in wavenumber $\left(\mathrm{cm}^{-1}\right)$. High-resolution mass spectra (HRMS)<smiles>CCOC(=O)/C=C/C[C@H]1OC(C)(C)O[C@@H]1C(=O)/C=C/c1ccccc1</smiles><smiles>C=CCC1C[C@H]2OC(C)(C)O[C@H]2C(/C=C/c2ccccc2)O[C@@H]1/C=C/c1ccccc1</smiles><smiles>O=C1C=CC[C@H](/C=C/C[C@H]2C[C@H](O)[C@H](O)[C@H](/C=C/c3ccccc3)O2)O1</smiles>

Scheme 4 Synthesis of cryptopyranmoscatone B4 (6). Reagents and conditions: (a) DIBAL- $-\mathrm{H}_{,} \mathrm{CH}_{2} \mathrm{Cl}_{2},-78{ }^{\circ} \mathrm{C}, 85 \%$; (b) $t$-BuOK, $\mathrm{THF},-78{ }^{\circ} \mathrm{C}, 0.5 \mathrm{~h}, 90 \%$; (c) (i) DIBAL-H, $\mathrm{CH}_{2} \mathrm{Cl}_{2},-78^{\circ} \mathrm{C}, 2 \mathrm{~h}$; (ii) $\mathrm{Ph}_{3} \mathrm{P}=\mathrm{CH}_{2}, n$-BuLi, THF, $-78^{\circ} \mathrm{C}, 60 \%$; (d) Grubbs-Il catalyst, $\mathrm{CH}_{2} \mathrm{Cl}_{2}$, reflux, $4 \mathrm{~h}, 90 \%$; (e) $\mathrm{TiCl}_{4}, \mathrm{CH}_{2} \mathrm{Cl}_{2}, 0{ }^{\circ} \mathrm{C}, 15 \mathrm{~min}$, $80 \%$. 
[ESI+] were obtained by using either a TOF or a double focusing spectrometer. ${ }^{1} \mathrm{H}$ NMR spectra were recorded at $300,400,500 \mathrm{MHz}$ and ${ }^{13} \mathrm{C}$ NMR spectra were obtained at $75,100,125 \mathrm{MHz}$ in $\mathrm{CDCl}_{3}$ solution unless otherwise mentioned. Chemical shifts are reported in ppm downfield from tetramethylsilane and coupling constants $(J)$ are reported in Hertz $(\mathrm{Hz})$. The following abbreviations are used to designate signal multiplicity: $\mathrm{s}=$ singlet, $\mathrm{d}=$ doublet, $\mathrm{t}=$ triplet, $\mathrm{q}=$ quartet, $\mathrm{m}=$ multiplet, $\mathrm{br}=$ broad.

\section{Ethyl (E)-4-((4R,5R)-5-Cinnamoyl-2,2-dimethyl-1,3-dioxolan-4- yl)but-2-enoate (7)}

To an ice-cooled solution of 2-(iodooxy)benzoic acid ( $1.8 \mathrm{~g}, 6.5 \mathrm{mmol}$ ) in anhydrous $\mathrm{CH}_{3} \mathrm{CN}(20 \mathrm{~mL})$ was added a solution of alcohol 20 (1.5 $\mathrm{g}, 4.3 \mathrm{mmol}$ ). The mixture was heated to reflux for $1 \mathrm{~h}$, and then allowed to cool to r.t. The solvent was removed under reduced pressure and the compound was purified by silica gel column chromatography (hexane/EtOAc, 8:2) to give 7.

Yield: $1.3 \mathrm{~g}$ (90\%); liquid; $[\alpha]_{\mathrm{D}}^{25}+9.5\left(c=0.26, \mathrm{CHCl}_{3}\right)$.

IR (neat): 3449, 2928, 2847, 1720, 1476, 1374, 1216, 1147, 1070, $771 \mathrm{~cm}^{-1}$.

${ }^{1} \mathrm{H} \mathrm{NMR}\left(\mathrm{CDCl}_{3}, 500 \mathrm{MHz}\right): \delta=7.7(\mathrm{~d}, J=16.0 \mathrm{~Hz}, 1 \mathrm{H}), 7.62-7.58(\mathrm{~m}$, $2 \mathrm{H}), 7.44-7.39(\mathrm{~m}, 3 \mathrm{H}), 7.25(\mathrm{~d}, J=7.8 \mathrm{~Hz}, 1 \mathrm{H}), 6.92(\mathrm{dt}, J=13.9$, $6.9 \mathrm{~Hz}, 1 \mathrm{H}), 5.86(\mathrm{dt}, J=15.7,1.4 \mathrm{~Hz}, 1 \mathrm{H}), 4.71(\mathrm{~d}, J=7.5 \mathrm{~Hz}, 1 \mathrm{H})$, $4.58-4.53(\mathrm{~m}, 1 \mathrm{H}), 4.13(\mathrm{q}, J=6.9 \mathrm{~Hz}, 2 \mathrm{H}), 2.47-2.40(\mathrm{~m}, 1 \mathrm{H}), 2.30-$ $2.21(\mathrm{~m}, 1 \mathrm{H}), 1.68(\mathrm{~s}, 3 \mathrm{H}), 1.43(\mathrm{~s}, 3 \mathrm{H}), 1.24(\mathrm{t}, J=7.0,3 \mathrm{H})$.

${ }^{13} \mathrm{C} \mathrm{NMR}\left(\mathrm{CDCl}_{3}, 75 \mathrm{MHz}\right): \delta=197.7,166.1,144.4,143.9,134.3,131.6$, 128.9, 128.7, 123.9, 121.1, 110.3, 81.9, 76.6, 60.2, 33.6, 27.2, 24.9, 14.1 .

MS (ESI): $m / z=367[\mathrm{M}+\mathrm{Na}]^{+}$.

\section{Ethyl $(E)-4-((4 R, 5 S)-5-[(R, E)-1-H y d r o x y-3-p h e n y l a l l y l]-2,2-d i-$ methyl-1,3-dioxolan-4-yl)but-2-enoate (21)}

To a solution of 7 ( $0.6 \mathrm{~g}, 1.7 \mathrm{mmol})$ in $\mathrm{MeOH}(15 \mathrm{~mL}), \mathrm{CeCl}_{3} \cdot 7 \mathrm{H}_{2} \mathrm{O}(0.85$ $\mathrm{g}, 2.2 \mathrm{mmol}$ ) was added, and the mixture was cooled to $0{ }^{\circ} \mathrm{C}$ and stirred for $10 \mathrm{~min}$ at that temperature. The resultant suspension was then cooled to $-78{ }^{\circ} \mathrm{C}$ and stirred for $10 \mathrm{~min}, \mathrm{NaBH}_{4}(0.2 \mathrm{~g}, 5.2 \mathrm{mmol})$ was added portionwise to the suspension and the mixture was stirred at the same temperature for $0.5 \mathrm{~h}$. After completion of the reaction (TLC) it was cautiously quenched by the addition of water ( $3 \mathrm{~mL})$. Excess $\mathrm{MeOH}$ was evaporated off and the resulting residue was diluted with water $(15 \mathrm{~mL})$ and extracted with EtOAc $(3 \times 10 \mathrm{~mL})$. The combined organic layers were washed with brine $(10 \mathrm{~mL})$, dried over anhydrous $\mathrm{Na}_{2} \mathrm{SO}_{4}$, filtered, concentrated under reduced pressure and purified by silica gel column chromatography (hexane/EtOAc, 7:3) to afford $\alpha, \beta$-unsaturated ester 21 .

Yield: $0.5 \mathrm{~g}$ (85\%); pale-yellow liquid; $[\alpha]_{\mathrm{D}}^{25}+39.5\left(c=0.23, \mathrm{CHCl}_{3}\right)$. IR (neat): 3447, 2948, 2857, 1735, 1238, 1170, 1039, $770 \mathrm{~cm}^{-1}$.

${ }^{1} \mathrm{H} \mathrm{NMR}\left(\mathrm{CDCl}_{3}, 500 \mathrm{MHz}\right): \delta=7.39(\mathrm{~d}, J=7.2 \mathrm{~Hz}, 2 \mathrm{H}), 7.32(\mathrm{t}, J=$ $6.9 \mathrm{~Hz}, 2 \mathrm{H}), 7.26(\mathrm{t}, J=3.3 \mathrm{~Hz}, 1 \mathrm{H}), 6.97(\mathrm{dt}, J=15.7,6.9 \mathrm{~Hz}, 1 \mathrm{H}), 6.70$ $(\mathrm{d}, J=15.8 \mathrm{~Hz}, 1 \mathrm{H}), 6.19(\mathrm{dd}, J=15.9,6.9 \mathrm{~Hz}, 1 \mathrm{H}), 5.92(\mathrm{dt}, J=15.7$, $1.5 \mathrm{~Hz}, 1 \mathrm{H}), 4.34-4.27(\mathrm{~m}, 2 \mathrm{H}), 4.21-4.13(\mathrm{~m}, 3 \mathrm{H}), 2.72-2.62(\mathrm{~m}$, $1 \mathrm{H}), 2.58-2.47(\mathrm{~m}, 2 \mathrm{H}), 1.54(\mathrm{~s}, 3 \mathrm{H}), 1.39(\mathrm{~s}, 3 \mathrm{H}), 1.28(\mathrm{t}, J=7.3 \mathrm{~Hz}$, $3 \mathrm{H})$.

${ }^{13} \mathrm{C} \mathrm{NMR}\left(\mathrm{CDCl}_{3}, 75 \mathrm{MHz}\right): \delta=166.2,144.6,136.2,128.5,128.0,127.6$, 126.6, 123.5, 108.5, 79.9, 75.6, 70.6, 60.2, 33.0, 27.6, 25.1, 14.2.

HRMS (ESI): $m / z[\mathrm{M}+\mathrm{Na}]^{+}$calcd. for $\mathrm{C}_{20} \mathrm{H}_{26} \mathrm{O}_{5} \mathrm{Na}$ : 369.1677; found: 369.1678.
$(R)-6-\{[(2 S, 4 R, 5 R, 6 R)-4,5-D i h y d r o x y-6-[(E)-s t y r y l] t e t r a h y d r o-2 H-$ pyran-2-yl]methyl\}-5,6-dihydro-2H-pyran-2-one (3)

To a stirred solution of $\mathbf{2 3}$ (30 mg, $0.08 \mathrm{mmol})$ in anhydrous $\mathrm{CH}_{2} \mathrm{Cl}_{2}(5$ $\mathrm{mL}), \mathrm{TiCl}_{4}(0.01 \mathrm{~mL}, 0.08 \mathrm{mmol})$ was added at $0{ }^{\circ} \mathrm{C}$ and the reaction mixture was stirred at this temperature for $1 \mathrm{~h}$. The reaction was quenched with solid $\mathrm{NaHCO}_{3}$, and the mixture was filtered. The solvent was removed under reduced pressure and the residue was purified by silica gel column chromatography (EtOAc/hexane, 50\%) to afford 3.

Yield: $21 \mathrm{mg}$ (80\%); colorless oil; $[\alpha]_{\mathrm{D}}^{25}+5.2\left(c=0.1, \mathrm{CHCl}_{3}\right)$. IR (neat): 3468, 2987, 2983, 1714, 1648, 1452, 1254, 1168, $769 \mathrm{~cm}^{-1}$. ${ }^{1} \mathrm{H} \mathrm{NMR}\left(\mathrm{CDCl}_{3}, 500 \mathrm{MHz}\right): \delta=7.437 .23(\mathrm{~m}, 5 \mathrm{H}), 6.95-6.84(\mathrm{~m}, 1 \mathrm{H})$, $6.68(\mathrm{~d}, J=16.0 \mathrm{~Hz}, 1 \mathrm{H}), 6.23(\mathrm{dd}, J=16.0,6.9 \mathrm{~Hz}, 1 \mathrm{H}), 6.09-5.99(\mathrm{~m}$, $1 \mathrm{H}), 4.83-4.90$ (m, $1 \mathrm{H}), 4.0-4.15$ (m, $1 \mathrm{H}), 3.88-3.67$ (m, $2 \mathrm{H}), 3.66-$ $3.52(\mathrm{~m}, 1 \mathrm{H}), 2.45-2.40(\mathrm{~m}, 1 \mathrm{H}), 2.34-2.28(\mathrm{~m}, 1 \mathrm{H}), 2.02-1.91(\mathrm{~m}$, $2 \mathrm{H}), 1.87-1.79(\mathrm{~m}, 1 \mathrm{H}), 1.65-1.50(\mathrm{~m}, 1 \mathrm{H})$.

${ }^{13} \mathrm{C} \mathrm{NMR}\left(\mathrm{CDCl}_{3}, 75 \mathrm{MHz}\right): \delta=164.4,145.2,136.6,132.3,128.6,127.9$, 126.5, 125.8, 121.4, 78.4, 76.4, 74.3, 71.0, 69.4, 41.3, 35.2, 29.9.

HRMS (ESI): $m / z$ [M + Na $]^{+}$calcd. for $\mathrm{C}_{19} \mathrm{H}_{22} \mathrm{O}_{5} \mathrm{Na}$ : 353.1365; found: 353.1366.

Ethyl (E)-4-\{(4R,5S)-5-[(S,E)-1-Hydroxy-3-phenylallyl]-2,2-dimethyl-1,3-dioxolan-4-yl\}but-2-enoate (24)

A stirred solution of $\mathbf{7}(0.6 \mathrm{~g}, 1.7 \mathrm{mmol})$ in $\mathrm{CH}_{2} \mathrm{Cl}_{2}(10 \mathrm{~mL})$ was cooled to $-78^{\circ} \mathrm{C}$, then DIBAL-H (1.6 M in toluene, $\left.2.2 \mathrm{~mL}\right)$ was added slowly. After $1 \mathrm{~h}$, the reaction was quenched with $\mathrm{MeOH}(10 \mathrm{~mL})$ and sodium potassium tartrate $(15 \mathrm{~mL})$, and stirred at r.t. for $0.5 \mathrm{~h}$. The layers were separated and the aqueous layer was extracted with $\mathrm{CH}_{2} \mathrm{Cl}_{2}(3 \times 20$ $\mathrm{mL})$. The combined organic layers were washed with brine $(2 \times 10$ $\mathrm{mL}$ ), dried over anhydrous $\mathrm{Na}_{2} \mathrm{SO}_{4}$, filtered, and concentrated in vacuo to afford the pure $\alpha, \beta$-unsaturated ester 24 .

Yield: $1.6 \mathrm{~g}(85 \%)$; pale-yellow oil; $[\alpha]_{\mathrm{D}}{ }^{25}+27.3\left(c=0.2, \mathrm{CHCl}_{3}\right)$.

IR (neat): 3446, 2984, 2977, 1643, 1449, 1372, 1264, 1168, 1058, $977 \mathrm{~cm}^{-1}$.

${ }^{1} \mathrm{H} \mathrm{NMR}\left(\mathrm{CDCl}_{3}, 500 \mathrm{MHz}\right): \delta=7.43-7.39(\mathrm{~m}, 2 \mathrm{H}), 7.33(\mathrm{t}, J=7.1 \mathrm{~Hz}$, $2 \mathrm{H}), 7.28-7.25(\mathrm{~m}, 1 \mathrm{H}), 7.04(\mathrm{dt}, J=15.6,6.9 \mathrm{~Hz}, 1 \mathrm{H}), 6.69$ (dd, $J=$ $16.0,1.0 \mathrm{~Hz}, 1 \mathrm{H}), 6.37(\mathrm{dd}, J=16.0,6.1 \mathrm{~Hz}, 1 \mathrm{H}), 5.94(\mathrm{dt}, J=15.6$, $1.5 \mathrm{~Hz}, 1 \mathrm{H}), 4.22-4.37(\mathrm{~m}, 1 \mathrm{H}), 4.36-4.31(\mathrm{~m}, 1 \mathrm{H}), 4.19(\mathrm{q}, J=7.1 \mathrm{~Hz}$, $2 \mathrm{H}), 4.08(\mathrm{dd}, J=7.7,5.7 \mathrm{~Hz}, 1 \mathrm{H}), 2.76-2.69(\mathrm{~m}, 1 \mathrm{H}), 2.63-2.54(\mathrm{~m}$, $1 \mathrm{H}), 1.47$ (s, $3 \mathrm{H}), 1.35$ (s, $3 \mathrm{H})$.

${ }^{13} \mathrm{C} \mathrm{NMR}\left(\mathrm{CDCl}_{3}, 75 \mathrm{MHz}\right): \delta=166.4,145.6,136.3,132.0,129.1,128.5$, 127.9, 126.6, 123.3, 108.6, 79.8, 76.3, 70.9, 60.2, 33.0, 27.9, 25.5, 14.2.

HRMS (ESI): $m / z$ [M + Na] ${ }^{+}$calcd. for $\mathrm{C}_{20} \mathrm{H}_{26} \mathrm{O}_{5} \mathrm{Na}$ : 369.1677; found: 369.1676.

$(R)-6-[(E)-3-\{(2 S, 4 R, 5 R, 6 S)-4,5-D i h y d r o x y-6-[(E)-s t y r y l] t e t r a h y-$ dro-2H-pyran-2-yl\}prop-1-en-1-yl]-5,6-dihydro-2H-pyran-2-one (6)

To a stirred solution of $\mathbf{2 6}(20 \mathrm{mg}, 0.25 \mathrm{mmol})$ in anhydrous $\mathrm{CH}_{2} \mathrm{Cl}_{2}(5$ $\mathrm{mL}), \mathrm{TiCl}_{4}(0.03 \mathrm{~mL}, 0.25 \mathrm{mmol})$ was added at $0{ }^{\circ} \mathrm{C}$. The mixture was stirred at this temperature for $0.5 \mathrm{~h}$, then the reaction was quenched with solid $\mathrm{NaHCO}_{3}$ and the mixture was filtered. The solvent was removed under reduced pressure and the residue was purified by silica gel column chromatography (EtOAc/hexane, 1:1) to afford 6.

Yield: $14 \mathrm{mg}$ (80\%); pale-yellow oil; $[\alpha]_{\mathrm{D}}^{25}+5.2\left(c=0.1, \mathrm{CHCl}_{3}\right)$. IR (neat): 3448, 2983, 2854, 1712, 1648, 1542, 1484, 1263, 1090, $755 \mathrm{~cm}^{-1}$. 
${ }^{1} \mathrm{H}$ NMR $\left(\mathrm{CDCl}_{3}, 500 \mathrm{MHz}\right): \delta=7.43-7.37(\mathrm{~m}, 2 \mathrm{H}), 7.30(\mathrm{t}, J=7.7 \mathrm{~Hz}$, $2 \mathrm{H}), 7.25-7.19(\mathrm{~m}, 1 \mathrm{H}), 6.87(\mathrm{dt}, J=16.1,5.4 \mathrm{~Hz}, 1 \mathrm{H}), 6.68(\mathrm{dd}, J=$ 16.0, $1.1 \mathrm{~Hz}, 1 \mathrm{H}), 6.27(\mathrm{dd}, J=16.1,5.4 \mathrm{~Hz}, 1 \mathrm{H}), 6.04(\mathrm{dt}, J=9.6$, $1.7 \mathrm{~Hz}, 1 \mathrm{H}$ ), 5.96-5.87 (m, $1 \mathrm{H}), 5.70$ (dd, $J=15.5,6.4 \mathrm{~Hz}, 1 \mathrm{H}), 4.94-$ $4.87(\mathrm{~m}, 1 \mathrm{H}), 4.53-4.47(\mathrm{~m}, 1 \mathrm{H}), 4.05(\mathrm{dd}, J=9.1,4.6 \mathrm{~Hz}, 1 \mathrm{H}), 4.01-$ $3.92(\mathrm{~m}, 1 \mathrm{H}), 3.82$ (dd, $J=9.2,4.7 \mathrm{~Hz}, 1 \mathrm{H}), 2.47-2.36(\mathrm{~m}, 3 \mathrm{H}), 2.34-$ $2.24(\mathrm{~m}, 1 \mathrm{H}), 1.92(\mathrm{dt}, J=14.9,2.9 \mathrm{~Hz}, 1 \mathrm{H}), 1.80-1.71(\mathrm{~m}, 1 \mathrm{H})$.

${ }^{13} \mathrm{C} \mathrm{NMR}\left(\mathrm{CDCl}_{3}, 75 \mathrm{MHz}\right): \delta=164.0,144.7,136.1,133.6,131.0,129.6$, 128.7, 128.3, 126.5, 124.9, 121.5, 77.2, 76.1, 69.7, 68.3, 65.2, 37.2, 33.6, 28.8 .

HRMS (ESI): $m / z[\mathrm{M}+\mathrm{Na}]^{+}$calcd. for $\mathrm{C}_{21} \mathrm{H}_{24} \mathrm{O}_{5} \mathrm{Na}$ : 379.1521; found: 379.1520 .

\section{Funding Information}

The authors thank the Council of Scientific and Industrial Research (CSIR), New Delhi, India, for financial support as part of a five year programme under the title ORIGIN (CSC-0108). A.M. thanks the Council of Scientific and Industrial Research (CSIR), New Delhi, India, for financial assistance in the form of a Research Fellowship.

\section{Supporting Information}

Experimental procedures, spectroscopic data, copies of ${ }^{1} \mathrm{H}$ NMR ${ }^{13} \mathrm{C}$ NMR and NOESY spectra are available. Supporting information for this article is available online at https://doi.org/10.1055/s-0036-1591931.

\section{References}

(1) (a) de Fátima, A.; Kohn, L. K.; de Carvalho, J. E.; Pilli, R. A. Bioorg. Med. Chem. 2006, 14, 622. (b) Marco, J. A.; Carda, M. Recent Advances in the Field of Naturally Occurring 5,6-Dihydropyran-2ones, In Natural Lactones and Lactams. Synthesis, Occurrence and Biological Activity; Janecki, T., Ed.; Wiley-VCH: Weinheim, 2014, 51-100.

(2) Wach, J.-Y.; Güttinger, S.; Kutay, U.; Gademann, K. Bioorg. Med. Chem. Lett. 2010, 20, 2843.

(3) Mosaddik, M. A.; Haque, M. E. Phytother. Res. 2003, 17, 1155.

(4) de Fátima, A.; Martins, C. V. B.; de Resende, M. A.; Magalhaes, T. F. F.; Lima, B. H. S.; Watanabe, G. A.; Ruiz, A. L. T. G.; de Carvalho, J. E.; Pilli, R. A. Lett. Drug Des. Discovery 2008, 5, 74.

(5) Kabir, K. E.; Khan, A. R.; Mosaddik, M. A. J. Appl. Entomol. 2003, $127,112$.

(6) Cavalheiro, A. J.; Yoshida, M. Phytochemistry 2000, 53, 811.

(7) Sturgeon, C. M.; Cinel, B.; Díaz-Marrero, A. R.; McHardy, L. M.; Ngo, M.; Andersen, R. J.; Roberge, M. Cancer Chemother. Pharmacol. 2008, 61, 407 .
(8) Giocondo, M. P.; Bassi, C. L.; Telascrea, M.; Cavalheiro, A. J.; Bolzani, V. S.; Silva, D. H. S.; Agustoni, D.; Mello, E. R.; Soares, C. P. Rev Ciênc Farm Básica Apl. 2009, 30, 315.

(9) Drewes, S. E.; Horn, M. M.; Ramesar, N. S.; Ferreira, D.; Nel, R. J. J.; Hutchings, A. Phytochemistry 1998, 49, 1683.

(10) Zschocke, S.; VanStaden, J. J. Ethnopharmacol. 2000, 71, 473.

(11) (a) Sabitha, G.; Sandeep, A.; Senkara Rao, A.; Yadav, J. S. Eur. J. Org. Chem. 2013, 6702. (b) Sabitha, G.; Praveen, A.; Kishore, Das. S. Synthesis 2015, 47, 330. (c) Raju, A.; Shiva Raju, K.; Sabitha, G. Tetrahedron: Asymmetry 2015, 26, 948. (d) Sabitha, G.; Senkara Rao, A.; Yadav, J. S. Tetrahedron: Asymmetry 2011, 22, 866. (e) Marco, J. A.; Carda, M.; Murga, J.; Falomir, E. Tetrahedron 2007, 63, 2929.

(12) Sabitha, G.; Reddy, S. S. S.; Yadav, J. S. Tetrahedron Lett. 2010, 51, 6259.

(13) Sabitha, G.; Reddy, S. S. S.; Yadav, J. S. Tetrahedron Lett. 2011, 52, 2407.

(14) Maheswara Reddy, A.; Sabitha, G.; Sirisha, K. RSC Adv. 2015, 5, 35746.

(15) Sabitha, G.; Raju, A.; Nagendra Reddy, C.; Yadav, J. S. RSC Adv. 2014, 4, 1496

(16) (a) Maram, L.; Parigi, R. R.; Das, B. Tetrahedron 2016, 72, 7135. (b) Ping, Li. Z.; Dong, W.; Junhui, Z. J. Chem. Res. 2016, 40, 331.

(17) The diastereomeric ratio of the product was determined by using a Shimadzu high-performance liquid-chromatography (HPLC) system equipped with a chiral HPLC column (Chiralcel OD) and a UV detector at an absorbance of $254 \mathrm{~nm}$. Eclipse XDB C18 (150 × $4.6 \mathrm{~mm}, 5$ (m column) and a solvent system of $60 \%$ acetonitrile in $0.1 \% \mathrm{FA}$ at a flow rate of $1.0 \mathrm{~mL} / \mathrm{min}$ were used. tR: 7.8 and $8.4 \mathrm{~min}$.

(18) Hansen, T. M.; Florence, G. J.; Lugo-Mas, P.; Chen, J.; Abrams, J. N.; Forsyth, C. J. Tetrahedron Lett. 2003, 44, 57.

(19) Prasad, K. R.; Phaneendra, G. Tetrahedron 2012, 68, 7489.

(20) (a) Fuwa, H.; Yamaguchi, H.; Sasaki, M. Org. Lett. 2010, 12, 1848. (b) Hiebel, M.-A.; Pelotier, B.; Piva, O. Tetrahedron Lett. 2010, 51, 5091.

(21) (a) Brown, H. C.; Jadhav, P. K. J. Am. Chem. Soc. 1983, 105, 2092. (b) Brown, H. C.; Bhat, K. S.; Randad, R. S. J. Org. Chem. 1989, 54, 1570. (c) Bolshakov, S.; Leighton, J. L. Org. Lett. 2005, 7, 3809. (d) Chan, K.-P.; Ling, Y. H.; Loh, T.-P. Chem. Commun. 2007, 939.

(22) (a) Grubbs, R. H.; Miller, S. J.; Fu, G. C. Acc. Chem. Res. 1995, 28, 446. (b) Furstner, A. Angew. Chem. Int. Ed. 2000, 39, 3012. (c) Trnka, T. M.; Grubbs, R. H. Acc. Chem. Res. 2001, 34, 18. (d) Grubbs, R. H.; Chang, S. Tetrahedron 1998, 54, 4413.

(23) Drouet, K. E.; Theodorakis, E. A. Chem. Eur. J. 2000, 6, 1987.

(24) (a) Grubbs, R. H.; Chang, S. Tetrahedron 1998, 54, 4413. (b) Fuwa, H.; Yamaguchi, H.; Sasaki, M. Org. Lett. 2010, 12, 1848. (c) Hiebel, M.-A.; Pelotier, B.; Piva, O. Tetrahedron Lett. 2010, 51, 5091.

(25) (a) Sabitha, G.; Narjis, F.; Gopal, P.; Reddy, N. C.; Yadav, S. J. Tetrahedron: Asymmetry 2009, 20, 184. (b) Raju, A.; Sabitha, G. RSC Adv. 2015, 5, 34040. 